\title{
CHANGING PATTERNS OF CORVIDAE ON THE PRAIRIES
}

\section{S. HOUSTON, 863 University Drive, Saskatoon, Saskatchewan S7N 018}

Few groups of birds on the prairies have shown such pronounced changes over the last two centuries as have the Corvidae. Considered to be among the most intelligent bird species, it is interesting to note how they have adapted to changing conditions.

In the days of the buffalo, the raven was common and the magpie was videly distributed. With settlement, he magpie disappeared for 10 to 40 ears, while the raven vanished and he crow increased. The main esurgence of the magpie was within ny memory, for five summers of field vork near Yorkton in the 1940 's failed - located a single nest, and as late as 950 one could be out all day on a Christmas Bird Count at Yorkton with nly a single magpie sighting. Even nore recently, all three species have dapted to city life.

Prior to 1875 , ravens were present hroughout the breeding season cross the present prairie provinces, xtending down into the Dakotas. tewart ${ }^{33}$ has summarized the North lakota breeding season records, of ay, Maximilian, Audubon and Harris, ooper, and Grinnell, from 1823 rough 1874, chiefly along the hissouri River. Stewart ascribed the isappearance of the raven at the end f the century to the widespread use poisons and baited traps, but did ot mention the disappearance of the uffalo, whose carcasses provided the avenging ravens with carrion.

Records by Richardson, Hood and rummond in the $1820^{\prime} \mathrm{s}^{30}$ and by akiston in the late $1850^{\prime} \mathrm{s}^{3}{ }^{3}{ }^{4}$ incate that the raven was then comoner than the crow at Carlton and umberland. "All the year, common, ounds" was the notation for the ven by the Franklin expedition en, while "Summer, in flocks" was e corresponding entry for the crow. akiston found the raven "very generally distributed ... most numerous on the buffalo plains of the west" and studied a roost of over 50 birds near Carlton in winter. On an overland trip from Carlton to near the present site of Dinsmore, ${ }^{16}$ Blakiston found several nests of the raven and no nests of the crow. Indeed, the crow was so rare that Blakiston was "never fortunate enough to obtain a specimen."

The Earl of Southesk ${ }^{32}$ on July 6, 1858 recorded an empty raven nest near the present site of Craven in the Qu'Appelle Valley. Macoun,35 in his trips of 1872, 1879 and 1880, found the raven to be "frequent on the western plains," while the crow was "common on the western plains," possibly indicating more equal numbers of the two species than may have existed 50 years earlier.

After the buffalo declined, and as the first settlers appeared, the raven was no longer a breeding bird, though for some years it came south regularly in winter. Perhaps the last summer sighting was by Raine ${ }^{29}$ on June 16, 1893 at Rush Lake.

When John Gunn settled at Good Spirit Lake in 1888, the raven was quite common each winter for about 10 years. ${ }^{15}$ By the time Laurence B. Potter $^{26}$ settled at Eastend in 1901, the raven was virtually gone; he saw three in the next 15 years and then no more.

Coues, ${ }^{8}$ in his travels with the U.S. Northern Boundary Commission in 1873 and 1874 , found crows were "not very common ... though I saw a good many along the Souris river .... A nest containing five eggs, with the female parent, was secured on the Quaking Ash (Poplar) River, June 26, 1874." In 1882-84, Ernest Thompson (Seton) ${ }^{35}$ similarly considered the two crow nests he found worthy of description in detail, and said it was only "common," hence much less 


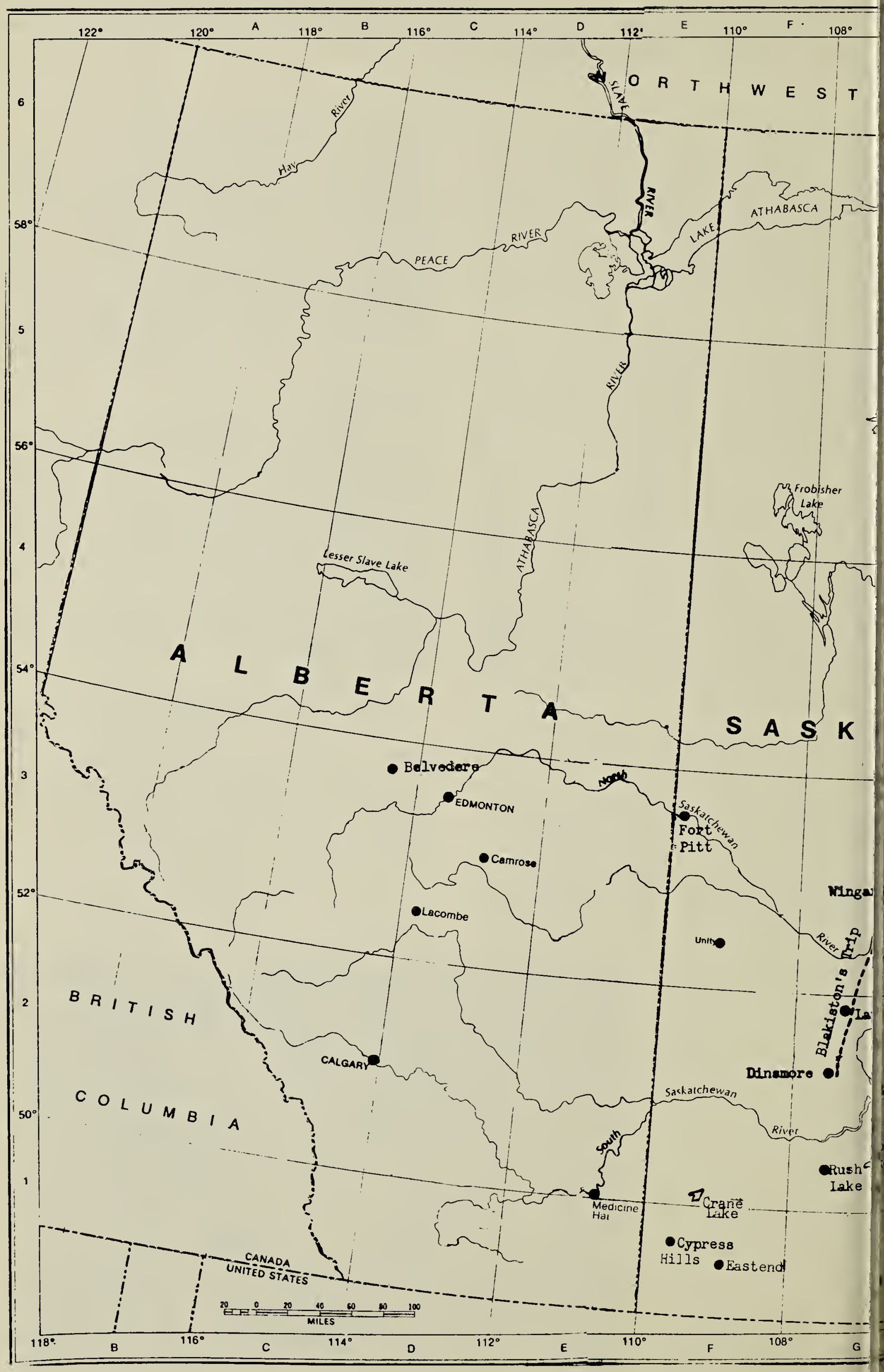




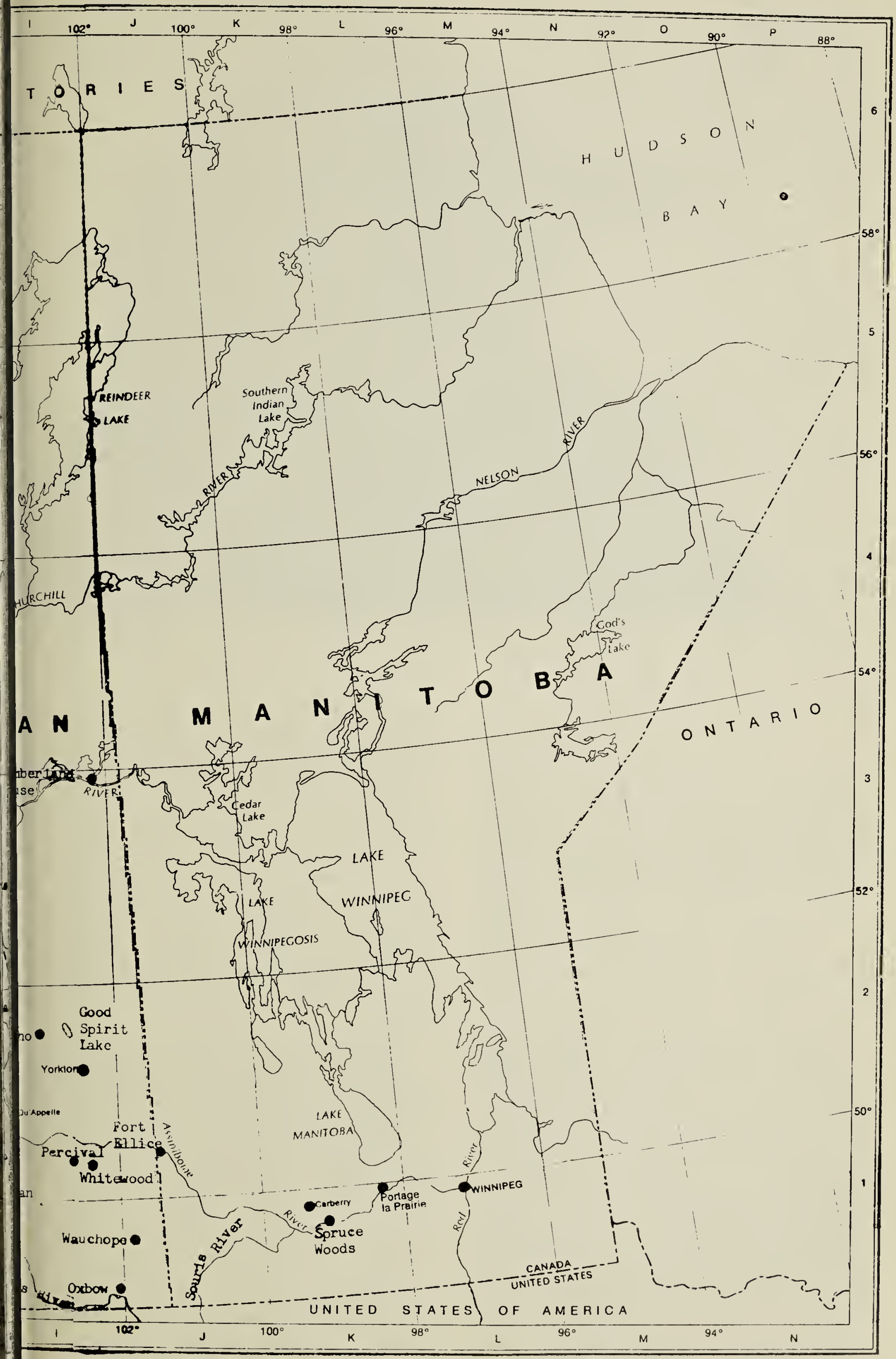


frequent than those species he listed as "abundant" or "very abundant."

The omnivorous crow adapted very rapidly to the increasing numbers of white men - traders, ranchers and then farmers. As early as 1885, George Guernsey ${ }^{35}$ considered the crow to be common, his highest ranking of frequency, at Fort Qu'Appelle; and Spreadborough in 1892 considered them numerous at Indian Head, with a nest in a willow on May 6. By 1895, Spreadborough said they were "found in pairs nearly all over Saskatchewan ... wherever there was wood ... common at Crane Lake, Medicine Hat, Cypress Hills, Moose Jaw, and around Old Wives Lake and creek, also at Wood Mountain ... May 8th, 1894, examined a number of nests at Medicine Hat, but found only one egg; a few were breeding at Crane Lake, June 12th; found a nest with four young ones; at the east end of Cypress Hills a few pairs were breeding the last week in June." Also in 1885, Loring ${ }^{17}$ found the crow abundant at Wingard, and Edward Arnold ${ }^{1}$ near Fort Qu'Appelle saw crows "flying around in all directions with eggs in their bills."

Although they now qualified as "common", crows had not yet achieved a fraction of their present numbers. A. C. Bent, ${ }^{2}$ in his 1905 and 1906 visits to the Maple Creek area, saw only a few pairs of crows, mostly near Crane Lake, finding two nests the first year and three the second. As late as 1922, C. G. Harrold ${ }^{12}$ saw only half a dozen pairs of crows at Old Wives Lake.

The explanation is simple. Because of annual prairie fires, there were very few trees. Indeed, when the settlers arrived, there were only a few shrubs around the wet margins of sloughs and occasional trees in protected river valleys. When the Houstons settled at Tyvan in 1903, crows occurred, but were not common because they lacked nesting sites anywhere nearby for many years; their numbers increased later. ${ }^{24} \mathrm{H} . \mathrm{H}$. Pittman, ${ }^{25}$ who first visited Wauchope in 1905 and 1907, and then settled there in 1913, reported how the crows increased in southeastern Saskatchewan, which after the turn of the century, "since the choking of the prairie fires, is rapidly becoming covered with little groups of trees, or bluffs, and in those the crows nest plentifully." L. B. Potter ${ }^{26}$ recorded that crows increased continuously in the Cypress Hills from his arrival in 1901 until about 1930.

Simultaneously, further north the settlers began to make clearings in the poplar and mixed forest, and to plant crops. The resulting diversity allowed such areas to support an increased crow population.

It is less obvious why crows more recently have settled in residential areas of our cities, though it may relate in part to a rather recent reticence to use firearms, even $B B$ guns, within the city. During our firs six years in Saskatoon, it was an annual ritual to drive into the country ir late March to seek the first crow of the year. Occasionally a flock would fly overhead or a few would perch ir trees by the river bank, but in the pas five years, there has been no need for a trip into the country, for crows stake out their territory on our residentia street and caw loudly at our windon in March. The invasion of residentia streets by breeding crows has oc. curred over the last ten years. The firs nest record for University Drive wa: in 1968 and by 1970 the Saskatoor bird record cards, as reported in Saskatoon Bird Review and then ir Saskatoon Field Notes, began tc report crows in residential area throughout May and June for the firs time.

Somewhat earlier, in the 1950 's, and somewhat further north, at Princ Albert ${ }^{17}$ and Nipawin, ravens becam "citified," losing their fear of man and appearing throughout the winter of city streets. Maurice Street ${ }^{34}$ reporte that about 1953, ravens "began ti enter Nipawin in search of garbag scraps or any other tidbit ... as man as 40 ravens have been observed nea the depot awaiting their breakfast. A many as a dozen or more have bee seen at one time perched o telephone or power poles along Firs 


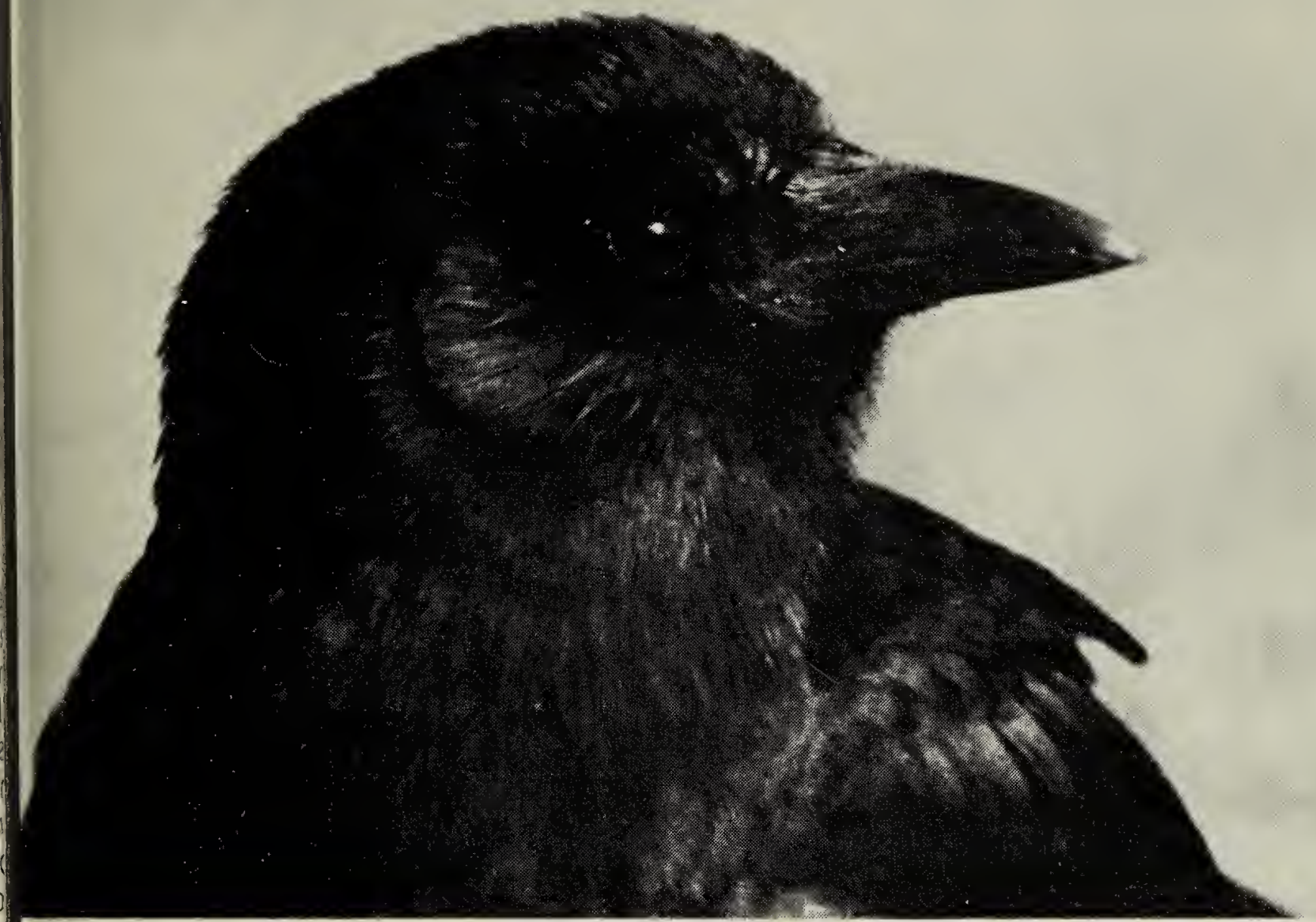

Common Crow

F. W. Lahrman

Avenue, Nipawin's main thoroughare. From the poles, they fly down to the street in search of food, walking bout and only reluctantly moving ut of the way of traffic - pedestrians or cars."

The magpie has perhaps the most nteresting story of all. Andrew raham's extensive natural history bservations from Hudson's Bay, 767-1791,38 stated that magpies "are lenty in the interior part of the ountry...our people meet with hem inland at all seasons." In 1822, at he Red River Colony, now Winnipeg, ev. John West ${ }^{37}$ listed the magpie as ne of only three winter birds "and hat but seldom." In the same decade, ichardson" ${ }^{30}$ recorded it as "plentiful $n$ the interior prairie lands of America ... only stray individuals passing to the eastward of ... Lake Vinnipeg."

As the buffalo retreated further vest, the magpie retreated as well. Blakiston ${ }^{3} 4$ in 1858 found it a resident luring the entire year on the
Saskatchewan, but only "occasionally observed" at Carlton; while H. Y. Hind $^{14}$ that year found it very numerous in the thin woods fringing the lakes near Fort Qu'Appelle. In 1873, A. R. C. Selwyn" found "a good many" along the North Saskatchewan from Fort Pitt to the present site of Langham.

Peter and Pascal Dumont and Matthew Cook told Frank L. Farley ${ }^{10}$ how the magpies were numerous near Camrose, Alberta, during the buffalo days "when flocks would follow the hunting parties and live on the refuse of the hunt," but they disappeared from that area in the early 1880 's. C. W. Nash told Ernest E. Thompson (Seton) ${ }^{35}$ that until about 1870 , magpies occurred in the Spruce Woods 20 to 30 miles west of Portage la Prairie. By 1875-1883, the magpie was very common only to the west of the Touchwood Hills and not seen east of Fort Ellice. ${ }^{20}$

When John Gunn settled at Good Spirit Lake in 1887, magpies were 


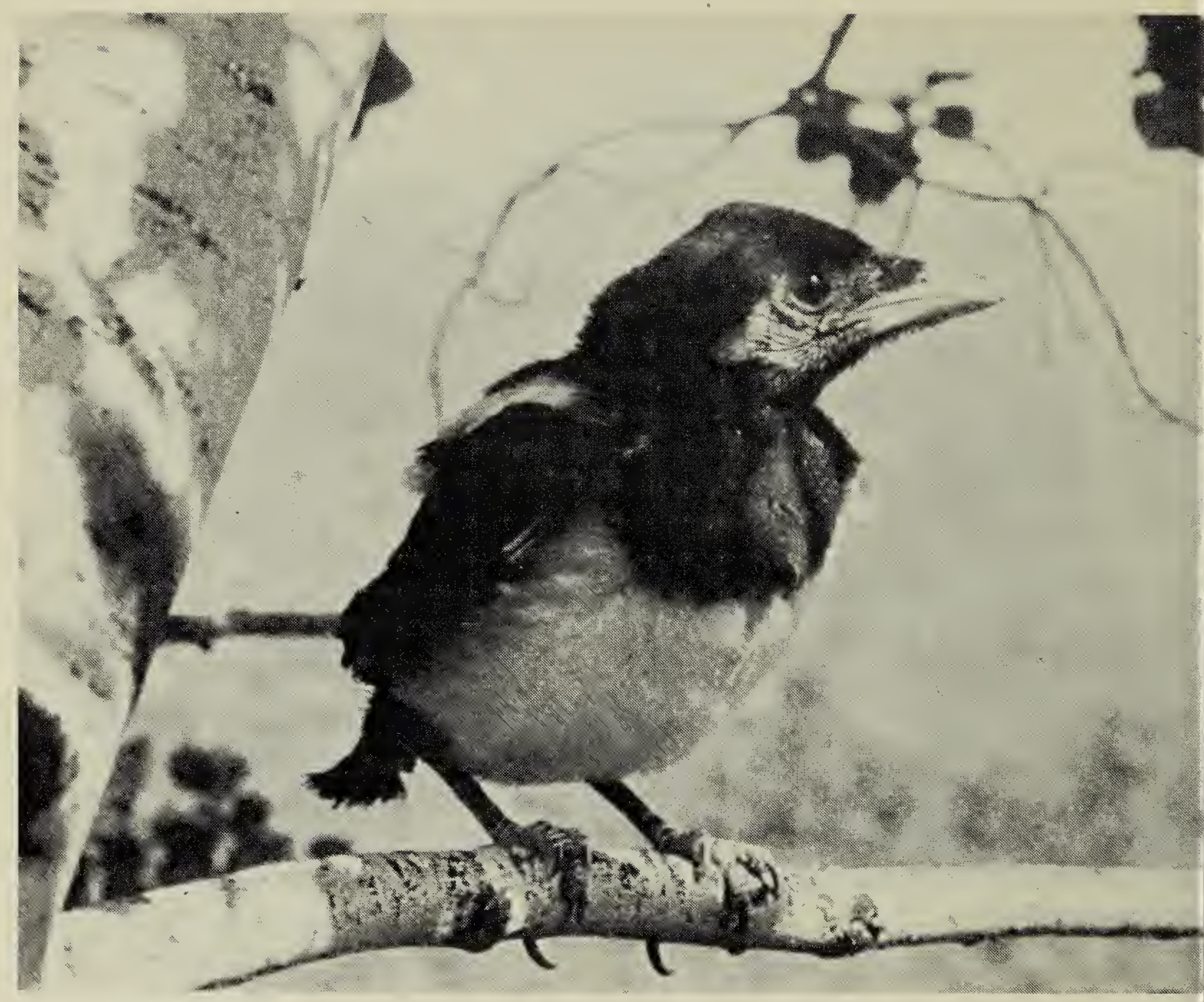

common for the first ten years, then practically disappeared. ${ }^{15}$ In 1891, Walter Raine ${ }^{28}$ was told that magpies occurred at Moose Jaw, but he saw none during his first two visits to Saskatchewan, and found no nests.

By the turn of the century, magpies were restricted to the foothills of the Rockies and the Cypress Hills. Laurence B. Potter ${ }^{26}$ found them common enough at Eastend from 1901 to 1904 , but then they disappeared for six years. This is confirmed by A. C. Bent's studies ${ }^{2}$ of 1905 and 1906 near Maple Creek, where none were seen during two successive summers, though an unused nest from a previous year was found.

Potter noted a gradual increase after the magpie returned to the southeastern slopes of the Cypress Hills in 1910. Meanwhile the forerunners of the Alberta resurgence reached Lacombe in $1911^{11}$ and spread to Belvedere, northwest of Edmonton, by $1919 .^{13}$

The annual reports of th Saskatchewan Game Commissioner told how magpies became noticeabl more common in the winter of 1922 23, when Robert Perrin of Maple Creek shot 26. In the following year they increased at Maple Creek, Laura Lestock, Whitewood and Oxbow.

S. Humphry ${ }^{19}$ reported that the firs pair appeared at Unity in 1926, tha they bred in 1931 and were commo by 1932. They appeared at Sheho it 1926, ${ }^{23}$ with step-like increases in 193 and again in 1949. They appeared a Percival in 1939 and were commo after 1934 (E. M. Callin, pers. comm.) They were first seen at Nipawin il 1930, with the first nest found $b$ Maurice G. Street in $1935 .{ }^{17}$ W. E. C Todd's Carnegie Museum ex pedition ${ }^{36}$ of 1932 to centra Saskatchewan found them local a Elbow. The two years of major magpi increase at Wauchope were 1939 an 
1949, and at Yorkton, 1951 and 1958. They reached La Ronge in 1958 (John Finch, fide $M$. Ross Lein), and that year all 32 Christmas Bird Counts recorded magpies. Since then magpies have remained as a very common or abundant bird throughout Saskatchewan, reaching even the most remote settlements of the far north. ${ }^{22}$

The movement into the streets of Saskatoon has occurred only in the past 10 years. Whereas previously a magpie might wander into our yard several times a year, since the fall of 1972 they have been almost daily visitors, and for four years the crow and the magpie have become the most conspicuous species to be seen and heard in the half-mile walk from my home to the University campus. Robert Lister tells me that magpies have similarly become year-round species in residential areas of Edmonton within the past 10 years.

The appearance of Merlins as a nesting species within residential areas of Saskatoon in the past five or six years has been possible because of the availability of crow and magpie nests for them to nest in. When one considers the destruction of eggs and young of smaller birds carried out by crows and magpies, it will be appreciated that the changing numbers of these species have far-ranging effects.

This material could not have been gathered without the help of my wife, Mary.

ARNOLD, E. 1896. An outing in Assiniboia, 1895. Oologist 12: 150-151.

BENT, A. C. 1907 and 1908. Summer birds of southwestern Saskatchewan. Auk 24: 407-430 and 25: 25-35.

BLAKISTON, T. 1859. Scraps from the far west. Zoologist 17: 6318-6325.

BLAKISTON, T. 1863. On birds collected and observed in the interior of British North America. Ibis 5: 39-87.

BRADSHAW, F. 1923. Report of the Chief Game Guardian for the year ended April 30, 1923. King's Printer, Regina, $51 \mathrm{pp}$.
6 BRADSHAW, F. 1924. Report of the Game Commissioner for the year ending April 30, 1924. King's Printer, Regina, 32 pp.

7 COUBEAUX, E. 1900. Contributions to the natural history of the northwest territories. Ottawa Naturalist 14: 24-31.

${ }^{8}$ COUES, E. 1878. Field-notes on birds observed in Dakota and Montana along the 49th parallel during the seasons of 1873 and 1874. Bull. U.S. Geol. and Geog. Survey Terr. 4: 545-661.

9 DEACON, E. 1894. Breeding notes of birds at Prince Albert, N.W.T. Biological Review of Ontario 1: 68-71.

10 FARLEY, F. L. 1925. Changes in the status of certain animals and birds during the past fifty years in central Alberta. Can. Field-Naturalist 39: 200-202.

11 FARLEY, F. L. 1932. Birds of the Battle River Region. Institute of Applied Arts, Edmonton, 85 pp.

12 HARROLD, C. G. 1933. Notes on the birds found at Lake Johnston and Last Mountain Lake, Saskatchewan, during April and May, 1822. Wilson Bulletin 45: $16-26$.

13 HENDERSON, A. D. 1923. The return of the magpie. Oologist 40: 142.

14 HIND, H. Y. 1860. Narrative of the ... Assiniboine and Saskatchewan exploring expedition of 1858. Longman, Green, Longman and Roberts, London. Vol. I, 494 pp.

15 HOUSTON, C. S. 1949. The birds of the Yorkton district, Saskatchewan. Can. Field-Naturalist 63: 215-241, 1949.

16 HOUSTON, C. S. 1976. A bird-watcher's outing in 1858. Sask. History 29: 14-25.

17 HOUSTON, C. S. and M. G. STREET. 1959. The birds of the Saskatchewan River, Carlton to Cumberland. Sask. Nat. Hist. Soc., spec. pub. 3, Regina. 205 pp.

18 HOUSTON, M. 1959. 17th annual Saskatchewan Christmas bird count, 1958. Blue Jay 17: 4-8.

19 HUMPHRY, S. 1933. Bird notes from Unity, Saskatchewan. Can. FieldNaturalist 47: 158.

20 MACOUN, J. 1883. Manitoba and the great north-west. Thomas C. Jack, London. 687 pp.

21 MACOUN, J. and J. M. MACOUN. 1909. Catalogue of Canadian birds. Government printing bureau, Ottawa, $761 \mathrm{pp}$. 
22 NERO, R. W. 1967. The birds of northeastern Saskatchewan. Sask. Nat. Hist. Soc., spec. pub. 6, Regina, 96 pp.

23 NIVEN, W. 1973. The land, the birds through 50 years in aspen parkland. Blue Jay 31: 223-229.

24 NIXON, M. 1973. Then and now. Blue Jay 31: 4-6.

25 PITTMAN, H. H. 1928. Mallards on the prairie. Bird-Lore 30: 5-7, 1928.

26 POTTER, L. B. 1930. Bird-life changes in 25 years in southwestern Saskatchewan. Can. Field-Naturalist 44: 147-149.

27 POTTER, L. B. 1943. Bird notes from south-western Saskatchewan. Can. Field-Naturalist 57: 69-74, 1943.

28 RAINE, W. 1892. Bird nesting in northwest Canada. Hunter Rose, Toronto, 197 pp.

29 RAINE, W. 1894. Bird-nesting in northwest Canada. Nidiologist: 2: 9-10.

30 RICHARDSON, J. and W. SWAINSON. 1832. Fauna Boreali-Americana. Vol. 2, the Birds. John Murray, London, 501 pp.

31 SELWYN, A. R. C. 1874. Notes on a journey through the north-west territory from Manitoba to Rocky Moun- tain House. Can. Naturalist, n.s., 7: 193-215.

32 SOUTHESK, J. Carnegie, Earl of. 1875. Saskatchewan and the Rocky Mountains. Edmonston and Douglas, Edinburgh, $448 \mathrm{pp}$.

33 STEWART, R. E. 1975. Breeding birds of North Dakota. Tri-College Center for Environmental Studies, Fargo, 295 pp.

34 STREET, M. G. 1958. A brief account of the status of the common raven in the Carrot River valley, 1919-1958. Blue Jay 16: 150.

35 THOMPSON (SETON), E. E. 1891. The birds of Manitoba. Proc. U.S. Natl. Museum 13: 457-643, 1891.

36 TODD, W. E. C. 1947. Notes on the birds of southern Saskatchewan. Annals Carnegie Museum 30: 383-421.

37 WEST, J. (no date). The British North West American Indians with Free Thoughts on the Red River Settlement. St. John's Cathedral, Winnipeg. (mimeo, 35 pp.)

38 WILLIAMS, G. (Ed.). 1969. Andrew Graham's observations on Hudson's Bay, 1767-91. Hudson's Bay Record Society, London, 423 pp.

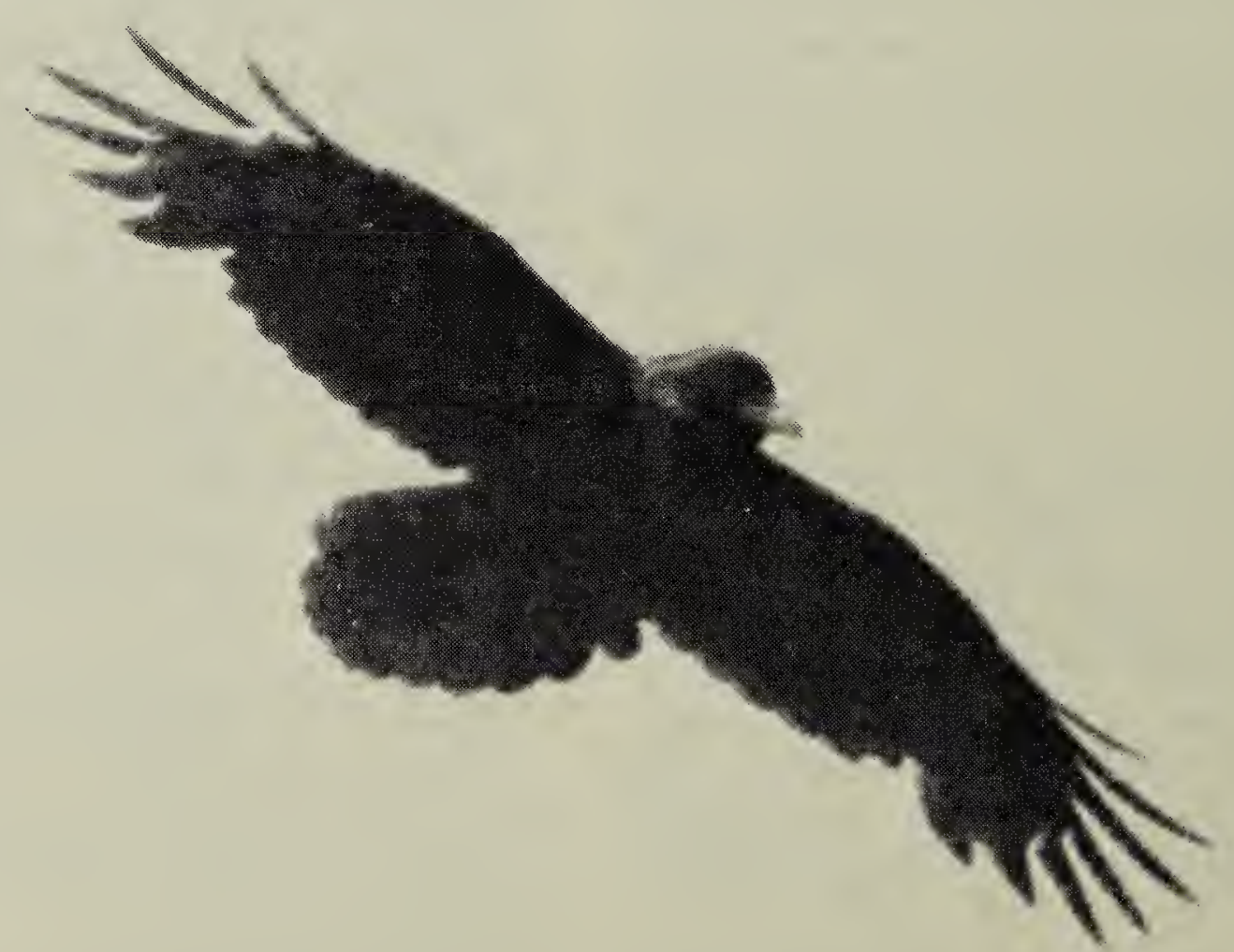

